\title{
General Intomology/Intomologia Geral Damage in fruits of mahogany caused by Hypsipyla grandella (Zeller) (Lepidoptera: Pyralidae) in Brasília, Brazil
}

\author{
Marcelo Tavares de Castro1 ${ }^{\bowtie}$, Sandro Coelho Linhares Montalvão² \& Rose Gomes Monnerat ${ }^{3}$
}

1. Faculdade de Agronomia e Medicina Veterinária, Universidade de Brasília - UnB, Brasília, Distrito Federal. 2. Departamento de Fitopatologia, Universidade de Brasília - UnB, Brasília, Distrito Federal. 3. Laboratório de Bactérias Entomopatogênicas, Embrapa Recursos Genéticos e Biotecnologia, Brasília, Distrito Federal.

\section{EntomoBrasilis 11 (1): o9-12 (2018)}

\begin{abstract}
This study aimed to evaluate qualitatively and quantitatively the Hypsipyla grandella (Zeller) damage in fruits of mahogany in Brasilia, Brazil. For this, fruits were collected and the analysis of each fruit was carried out by assessing the following parameters: fruit weight, fruit length and height, number of holes in fruits characteristic of $H$. grandella attack, size of the holes, number of larvae and pupae of $H$. grandella, number of seeds damaged and presence of other insects within the fruit. As a result, 190 (95\%) had holes made by the larvae, used primarily for their entry and for exit later as an adult. Most of the fruits showed only a single hole (81\%), but up to 5 holes were found in a single fruit. A single caterpillar can feed on various seeds, causing major damage when they attack together. Seventy-two (36\%) fruits had all the seeds damaged by $H$. grandella, especially those containing pupae. 183 larvae in different instars and 45 pupae were found. Only five caterpillars were found dead inside of fruit, representing $2.78 \%$ of the caterpillars.
\end{abstract}

Keywords: Forest Pest; Forest Entomology; Shoot Borer; Predation; Swietenia macrophylla.

\section{Danos em frutos de mogno causados pela Hypsipyla grandella (Zeller) (Lepidoptera: Pyralidae) em Brasília, Brasil}

Resumo. Este trabalho teve como objetivo avaliar qualitativamente e quantitativamente os danos provocados por Hypsipyla grandella (Zeller) em frutos de mogno em Brasília, Brasil. Para isso, frutos foram coletados e os seguintes parâmetros foram analisados: peso, comprimento, número de orifícios causados pela $H$. grandella, número de sementes danificadas e presença de outros insetos no interior dos frutos. Como resultado, 190 (95\%) frutos apresentaram orifícios feitos pela lagarta, usados primordialmente para sua entrada e posteriormente para a saída, quando adulto. A maioria dos frutos apresentou apenas um orifício (81\%), mas até cinco furos foram encontrados em um único fruto. Uma única lagarta pode se alimentar de várias sementes, causando grandes danos. Setenta e dois frutos (36\%) tinham todas as sementes danificadas por H. grandella, especialmente aqueles que apresentaram pupas. 183 lagartas em diferentes estádios e 45 pupas foram encontradas. Apenas cinco lagartas foram encontradas mortas dentro dos frutos, representando $2,78 \%$ do total.

Palavras-Chave: Broca do Mogno; Entomologia Florestal; Praga Florestal; Predação; Swietenia macrophylla.

T] he genus Hypsipyla (Lepidoptera) belong to the family Pyralidae, and has two species occurring in Brazil, Hypsipyla ferrealis Hampson, which attacks seeds of plants of the genus Carapa (Sapindales: Meliaceae), and Hypsipyla grandella (Zeller), which attacks various species of Meliaceae family, including Swietenia macrophylla King (Sapindales). The larvae of $H$. grandella are pinkish until the penultimate instar, becoming blue. The symptom of the attack on the tree can be seen by exuding gum and sawdust in shoots, and in the fruits the insect destroy the seeds (Lima 1940).

The mahogany fruit stay suspended in the tree and its ovulated berry type, encased by a woody capsule (CORDEIRO 2012). The fruits contain a varied number of seeds, up to 70 seeds (SNOOK 1998). The mahogany seeds are winged, 6 to $13 \mathrm{~cm}$ long by 1 to
$2.5 \mathrm{~cm}$ wide (Cordeiro 2012). A mature tree can produce up to 600 fruits or 30,000 seeds per year (GuLLison et al. 1996).

Several species of the Lepidoptera families Crambidae, Pyralidae and Tortricidae prey on the fruits and seeds of a large number of plant species (JANZEN 1971). According to ZHANG et al. (1997), seed predation is considered a predominant factor in the death of the seeds, reducing the supply or preventing germination and having consequences for the richness, diversity and distribution of plants.

Studies of the damage caused by insects to mahogany fruits in Brazil are practically nonexistent. Therefore, this study aimed to report the occurrence of $H$. grandella in Brasilia, Federal

\section{Edited by:}

William Costa Rodrigues

\section{Article History:}

Received: 18.viii.2017

Accepted: 21.i.2018
Corresponding author:

Marcelo Tavares de Castro

marceloengflorestal@gmail.com

- No ORCID record
Funding agencies:

$\leadsto$ CAPES 
District, and evaluate qualitatively and quantitatively the insect damage to mahogany fruit.

\section{MATERIAL AND METHODS}

Fruit was collected in the urban area of the city of Brasilia in the Federal District (DF) of Brazil, from February to May 2013. Trees can be found in various parts of the city, as can be seen in Table 1.

Table 1. Locations of collection of mahogany fruit in Brasilia/DF.

\begin{tabular}{cccc}
\hline Locale & Coordinates & $\begin{array}{c}\text { Number of } \\
\text { trees }\end{array}$ & Height (m) \\
\hline SQN 115 & $15.741325 \mathrm{~S} / 47.894049 \mathrm{~W}$ & 14 & $10-15$ \\
\hline SQN 116 & $15.738109 \mathrm{~S} / 47.892704 \mathrm{~W}$ & 28 & $10-15$ \\
\hline SQN 315 & $15.742704 \mathrm{~S} / 47.894265 \mathrm{~W}$ & 74 & $10-20$ \\
\hline SQN 316 & $15.737453 \mathrm{~S} / 47.895735 \mathrm{~W}$ & 108 & $5-20$ \\
\hline EMBRAPA & $15.729769 \mathrm{~S} / 47.902214 \mathrm{~W}$ & 8 & $10-12$ \\
\hline
\end{tabular}

According to Koppen's classification, the climate of the region is classified as AW (tropical climate with rains in summer and dry in winter), with the rainy season from October to April and dry from May to September. The average annual of the temperature is $21{ }^{\circ} \mathrm{C}$ and relative humidity is approximately $70 \%$ (WEATHerbase 2017).

The fruit collected was taken to the Laboratory of Bacteria and Invertebrates at Embrapa Genetic Resources and Biotechnology and the analysis of each fruit was carried out by assessing the following parameters: 1 . Fruit weight (g), using a digital scale; 2. Fruit Length and Height $(\mathrm{cm})$ with the aid of a millimeter ruler; 3. Number of holes in fruit characteristic of $H$. grandella attack; 4. Size of the holes $\left(\mathrm{cm}^{2}\right)$, with the aid of a millimeter ruler; 5 . Number of larvae of $H$. grandella; 6. Number of pupae of $H$. grandella; 7. Number of seeds damaged by $H$. grandella; 8 . Presence of other insects within the fruit.

Only caterpillars of $H$. grandella older than 3 rd instar were considered because they are easier to identify with greater accuracy. The seeds that had any kind of damage, even if only in the ward were also recorded. The identity of other insects was not recorded, just occurrence or absence.

Data were assessed for correlation between the number of larvae and the weight and size of the fruit and the number of damaged seeds and the number of larvae and pupae in each fruit. Levels of $1 \%$ and $5 \%$ probability were assessed by "t" test, with the aid of the Assistat 7.6 program.

\section{RESULTS AND DISCUSSION}

Two hundred fruits fallen to the ground, with or without characteristic symptoms of $H$. grandella attack, were collected. All fruits obtained were immature, with green seeds and with different sizes. Among the fruits collected, 190 had holes made by the larvae, used primarily for their entry and for exit later as an adult. Most of the fruits showed only a single hole (81\%), but up to 5 holes were found in a single fruit.

Often we observed droppings, spider webs and gum near the holes (Figure 1 - A and B), indicating the presence of the insect inside the fruit. After the entry of the caterpillar into the fruit, the seeds are severely damaged, particularly the endosperm, resulting in loss of viability. A single caterpillar can feed on various seeds, causing major damage when they attack together (Figure $1-C$ ). When the attack was very intense, the columella of the fruit was also damaged (Figure 1 - D), and often the insect stayed inside to transform into a pupa.

Despite having holes, not all fruit contained caterpillars. Of the total, $57 \%$ of the fruit had no individuals of $H$. grandella, despite showing damage to seeds and $24.5 \%$ had only one caterpillar. The fruit that had more than two caterpillars amounted to $18.5 \%$. Seventy-two fruits, from a total of 200, had all the seeds damaged by $H$. grandella, especially those containing pupae. First, the endosperm of the seed was attacked, followed by the wing and finally the columella. After the attack, with endosperm absent, the seed loses its vigor and germination, precluding its use for the production of seedlings. In a study by Querino et al. (2008) that analyzed the predation of seeds of Carapa guianensis Aubl. (Sapindales: Meliaceae) by Hypsipyla ferrealis Hampson in São João da Baliza / RR, the endosperm suffered different damage intensities, from minimal damage, with signs of caterpillars by the presence of galleries, up to completely destroyed, with food residue and / or remnants of cocoons.
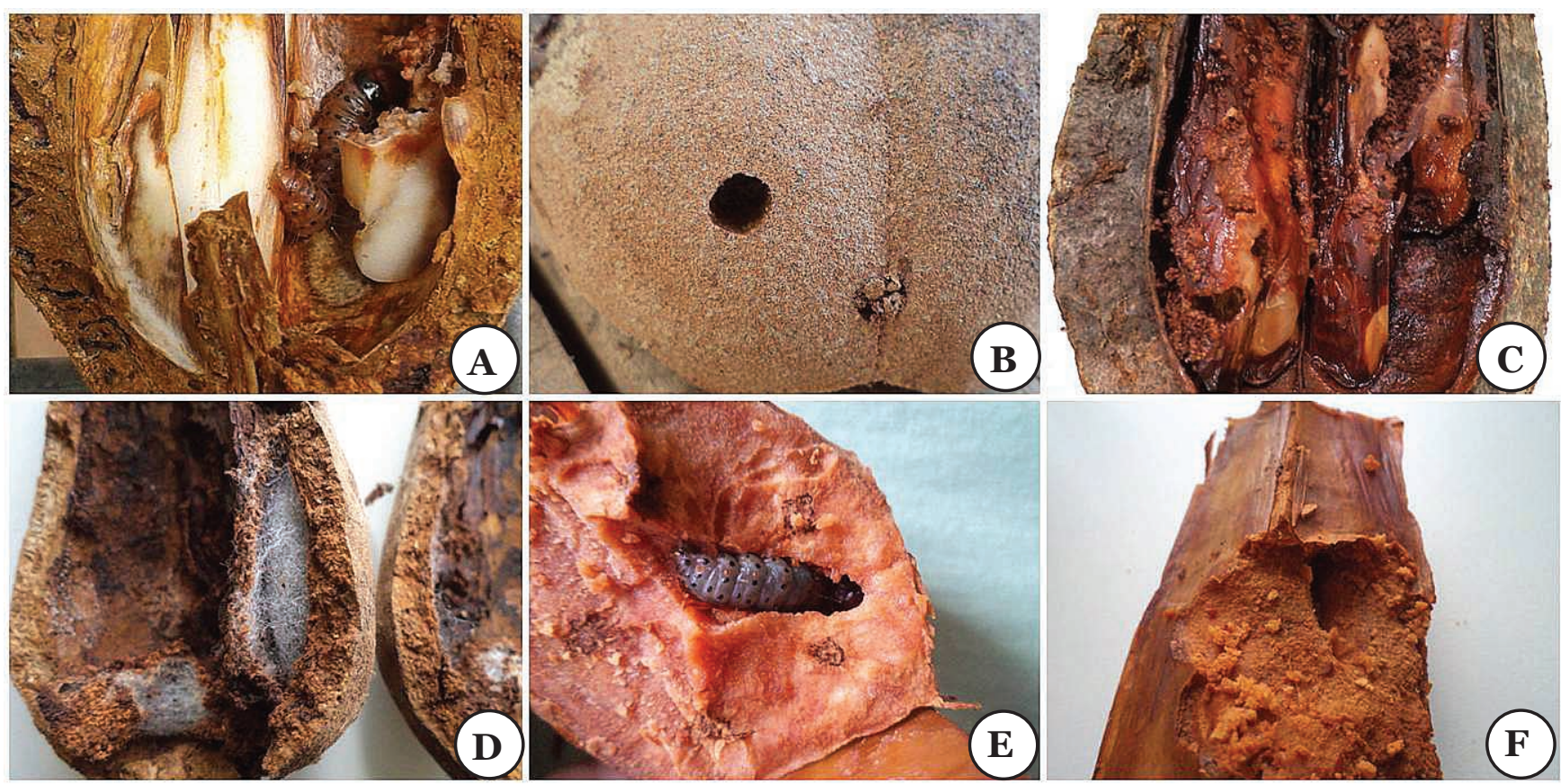

Figure 1. H. grandella attack of mahogany fruit in Brasília, Federal District. A- Caterpillar inside the fruit; B- Hole in the fruit made by the caterpillar; C- Seeds damaged by insects; D- Pupae inside the fruit; E- 6th instar caterpillar inside the fruit columella; F- Columella attacked. (Photos by M.T. Castro). 
183 larvae in different instars and 45 pupae were found. The smaller and younger larvae were usually found within the seeds and the largest and last instars near or within the columella fruit. Up to eight larvae of different sizes and instars were found in a single fruit, which may be an indication that this insect does not have cannibalistic habits. Of total fruits, $81 \%$ contained no pupae, $16.5 \%$ contained one pupa, $1.5 \%$ two pupae and $1 \%$ three pupae. Eighteen pupae were found abandoned and one was parasitized. All pupae were close to the fruit holes, presumably to facilitate the exit of the adult after emergence.

Only five caterpillars were found dead inside of fruit, representing $2.78 \%$ of the caterpillars $(n=180)$. Of these, three showed symptoms of bacterial infection, one fungal and the remaining one died from unknown causes. Mortality was lower than that observed by THomazini et al. (2011) when caterpillars were collected in the mahogany tree's terminal bud, reaching a total of nine out of 28 collected in May 2010 in Garça / SP. The natural larval mortality was $14.8 \%$ in the entire study. However, in a study by TAVERAS et al. (2004), in Costa Rica, the mortality rate was $24 \%$. The low mortality rate of insects in this study may be attributed to the fact that the insect is protected from possible predators and contamination by fungus and bacteria. The fact that the study be carried out in urban trees can also influence mortality, because there are fewer natural enemies in the city compared to the natural environment. No eggs were found on the fruits because these are preferably placed on shoots, twigs or leaves (GriJPMA \& GARA 1970; GrifFITHS 2001).

Insects of the orders Coleoptera, Diptera, Dermaptera and Isoptera were found inside the fruit, together or not with caterpillars and pupae of $H$. grandella. Many insects are possible opportunists, taking advantage of the holes caused by the entry of $H$. grandella and feeding on the insect excrement. Others are potential predators of the caterpillar, for example some representatives of Dermaptera. The insects of this order are voracious predators, i.e., with high capacity to attack and feed on different prey, especially eggs and immature forms of the orders Lepidoptera, Hemiptera, Coleoptera and Diptera (LEMos 1997), including Hypsiyla spp. (Querino et al. 2008). No harm caused by other insects to seeds of mahogany was observed.

The analysis of correlation between data generated, allowed the conclusion that the greater the size and weight of the fruit, the greater the number of caterpillars. This did not occur with the number of pupae, but the more holes the fruits possessed, the greater the number of empty pupae (Table 2).

Table 2. Correlation matrix between variables.

\begin{tabular}{|lccccc|}
\hline \multicolumn{1}{|c}{ Variable } & $\begin{array}{c}\text { Size of } \\
\text { Fruit }\end{array}$ & $\begin{array}{c}\text { Weight } \\
\text { of Fruit }\end{array}$ & $\begin{array}{c}\text { Number } \\
\text { of Holes }\end{array}$ & $\begin{array}{c}\text { Number } \\
\text { of } \\
\text { Larvae }\end{array}$ & $\begin{array}{c}\text { Number } \\
\text { of Pupae }\end{array}$ \\
\hline Size of Fruit & 1 & 0.8440 & -0.0386 & 0.2797 & -0.1829 \\
\hline Weight of Fruit & $* *$ & 1 & -0.0432 & 0.2974 & -0.2217 \\
\hline Number of Holes & $* *$ & $\mathrm{~ns}$ & 1 & -0.0040 & 0.2517 \\
\hline Number of Larvae & $* *$ & $* *$ & $\mathrm{Ns}$ & 1 & -0.0267 \\
\hline Number of Pupae & $* *$ & $* *$ & $* *$ & $\mathrm{~ns}$ & 1 \\
\hline
\end{tabular}

In which: ${ }^{* *}=$ significant at $1 \%$ level of probability $(\mathrm{p}<0.01) ; *$ significant at $5 \%$ level of probability $(0.01=<\mathrm{p}<0.05)$; ns = not significant $(\mathrm{p}>=0.05)$.

The caterpillars have a direct relationship with the number of damaged seeds, as well as the number of pupae (Table 3 ). Therefore, the greater the number of caterpillars, the more seeds that are damaged. In all the fruits in which pupae were found inside, all the seeds were damaged, which indicates that there is a high degree of seed predation by $H$. grandella.

Similar results were obtained by PINTO et al. (2013), where losses caused by predation of $H$. ferrealis and H. grandella in fruits of $C$. guianensis and Carapa procera DC. in the Adolpho Ducke Forest Reserve in the Amazon showed that these pests are limiting for these species, destroying fruit and seeds in the field. DiONisio et al. (2016) observed $H$. grandella and $H$. ferrealis attacking seeds of $C$. guianensis in Roraima, Brazil and JesusBarros et al. (2015) in Macapá, Brazil.

Table 3. Correlation matrix between the number of larvae and pupae and the number of damaged seeds.

\begin{tabular}{lccc}
\hline Variable & $\begin{array}{c}\text { Number } \\
\text { of Larvae }\end{array}$ & $\begin{array}{c}\text { Number } \\
\text { of Pupae }\end{array}$ & $\begin{array}{c}\text { Number } \\
\text { of Seeds } \\
\text { Damaged }\end{array}$ \\
\hline Number of Larvae & 1 & -0.0267 & 0.2751 \\
\hline Number of Pupae & $\mathrm{ns}$ & 1 & 0.3167 \\
\hline Number of Seeds Damaged & $* *$ & $* *$ & 1 \\
\hline
\end{tabular}

In which: ${ }^{* *}=$ significant at $1 \%$ level of probability $(\mathrm{p}<0.01) ;{ }^{*}=$ significant at $5 \%$ level of probability $(0.01=<\mathrm{p}<0.05)$; ns = not significant $(\mathrm{p}>=0.05)$.

All the collected fruits were fallen fact that can be explained by the presence of the $H$. grandella inside of the fruits. ROBERTs (1966, 1968) and GRIFFITHS (1997) reported the occurrence of premature fruit drop of the genus Khaya (Sapindales: Meliaceae) in Nigeria and Toona ciliata M. Roem. (Sapindales: Meliaceae) in Australia after the insect attack. In Australia, caterpillars round the fruit with a web at the point of abscission, where the fruit hangs in the top of the trees and the insect develops its entire cycle within the suspended fruit. No such behavior was observed for mahogany fruits, since the fruit is too heavy compared to the fruits of $T$. ciliata, and possibly the web would not support the weight.

From the analysis of the fruit it was possible to verify the presence of $H$. grandella in various mahogany trees located in Brasilia-DF. The attack of the mahogany fruit borer results in the maintenance of the insect in the locale in unfavorable seasons, serving as a source of inoculum for plants in nearby regions.

Preventive measures should be taken in order to reduce the population of $H$. grandella in Brasilia for Meliaceae future plantings to succeed, since this insect is the main obstacle to the establishment of various species within the family.

\section{REFERENCES}

Cordeiro, Y.E.M., 2012. Potencial de uso em recuperação de áreas degradadas: um estudo de três espécies nativas da Amazônia Oriental sob dois regimes hídricos. UFAM. 89 p.

Dionisio, L.F.S., A.C.S. Lima, T.M.M.G. Castro, R.G. Correia, W.B.R. Martins, V.S. Abreu, 2016. Ocorrência de Hypsipyla grandella Zeller (Lepidoptera, Pyralidae) no Sul do Estado de Roraima. EntomoBrasilis, 9: 97-100. DOI: https://doi.org/10.12741/ebrasilis.vgi2.547.

Griffiths, M.W., 2001. The biology and ecology of Hypsipyla shoot borers. In: Floyd, R.B. \& C. Hauxwell (Ed.) Hypsipyla Shoot Borers in Meliaceae: Proceedings of an International Workshop. Canberra: Australian Centre for International Agricultural Research. pp. 74-80.

Griffths, M.W., 1997. The biology and host relations of the red cedar tip moth, Hypsipyla robusta Moore (Lepidoptera: Pyralidae) in Australia. Ph.D. thesis, University of Queensland, Brisbae. $182 \mathrm{f}$.

Grijpma, P. \& R.I Gara, 1970. Studies on the shootborer Hypsipyla grandella (Zeller): II. Host preference of the larva. Turrialba, 20: 241-247.

Gullison, R.E., S.N. Panfil, J.J. Struose \& S.P. Hubbell, 1996. Ecology and management of mahogany (Swietenia macrophylla King) in the Chimanes Forest, Neni, Bolivia. Botanical Journal of the Linnean Society, 122: 9-34. DOI: https://doi.org/10.1111/j.1095-8339.1996.tb02060.x.

Janzen, D.H., 1971. Seed predation by animals. Annual Review of Ecology and Systematics, 2: 465-492. DOI: https://doi.org/10.1146/annurev.es.02.110171.002341.

Jesus-Barros, G.R.,A.C.Lira-Guedes, M.C. Guedes, G. GuabirabaRibeiro \& E.J. Barbosa, 2015. Registro da ocorrência de 
Hypsipyla ferrealis e Hypsipyla grandella (Lepidoptera: Pyralidae) em frutos de andirobeiras (Carapa guianensis, Meliaceae) em Macapá - AP, Brasil. Ciência Florestal, 25: 765-769. DOI: https://doi.org/10.5902/1980509819679.

Lemos, W.P., 1997. Biologia e exigências térmicas de Euborellia annulipes (Lucas, 1847) (Dermaptera: Anisolabididae), predador do bicudo-do-algodoeiro. Dissertação (Mestrado) Universidade Federal da Paraíba. 119 f.

Lima, A.C., 1940. Insetos do Brasil, Escola Nacional de Agronomia, Série Didática, $\mathrm{n}^{\circ} 3$.

Pinto, A.A., B.R. Teles, N. Anjos, S.E.M \& Couceiro, 2013. Predação de sementes de andiroba [Carapa guianensis Aubl. e Carapa procera DC. (Meliaceae)] por insetos na Amazônia. Revista Árvore, 37: 1115-1123. DOI: https://doi.org/10.1590/So100-67622013000600013.

Querino, R.B., H. Tonini, J.R., A.L. Marsaro Júnior, A.S. Teles \& J.A.M. Costa, 2008. Predação de Sementes de Andiroba (Carapa spp.) por Hypsipyla ferrealis Hampson (Lepidoptera: Pyralidae) em Roraima. Boletim de Pesquisa e Desenvolvimento, 5: 1-24.

Roberts, H., 1966. A survey of the important shoot, stem, wood, flower and fruit boring insects of the Meliaceae in Nigeria. Nigerian Forestry Information Bulletin, 15: 1-38.

Roberts, H., 1968. An outline of the biology of Hypsipyla robusta Moore, the shootborer of the Meliaceae (Mahoganies) of Nigeria, together with brief comments on two stem borers and one other lepidopteran fruit borer also found in Nigerian Meliaceae. Commonwealth Forestry, 47: 225-232.

Snook, L.K., 1998. Colheita sustentada da madeira de mogno (S. macrophylla) nas florestas de Yucatan de México. Conservação e desenvolvimento na floresta de Maya de Belize, de Guatemala e de México, p. 61-8o. In: Primack, R.B., D. Zuarra, H.A. Gallett, I. Ponciano, I. Timber, Tourists and People, Imprensa do Console, Washington DC: Island Press, USA. 446 p.

Taveras, R., L. Hilje \& M. Carballo, 2004. Development of Hypsipyla grandella (Zeller) (Lepidoptera: Pyralidae) in response to constant temperatures. Neotropical Entomology, 33: 1-6. DOI: https://doi.org/10.1590/S1519566X2004000100002.

Thomazini, M.J., V.H.P.Tedeschi\&J.R. de Meira, 2011. Incidência e danos da broca-das-meliáceas, Hypsipyla grandella, em mogno, no interior paulista. Colombo: Embrapa Florestas, Comunicado Técnico, 280: 1-6.

Weatherbase, 2017. Available on: <http://www.weatherbase. com >. [Accessed in: i.2017].

Zhang, J., F.A. Drummond, M. Liebman \& A. Hartke. 1997. Insect predation of seeds and plant population dynamics. Mafes Technical Bulletin, University of Maine. 163 p.

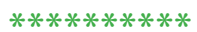

\section{Suggestion citation:}

de Castro, M.T., S.C.L. Montalvão \& R.G. Monnerat, 2018. Damage in fruits of mahogany caused by Hypsipyla grandella (Zeller) (Lepidoptera: Pyralidae) in Brasília, Brazil. EntomoBrasilis, 11 (1): 09-12.

Available on: $\underline{\text { doi:10.12741/ebrasilis.v11i1.690 }}$
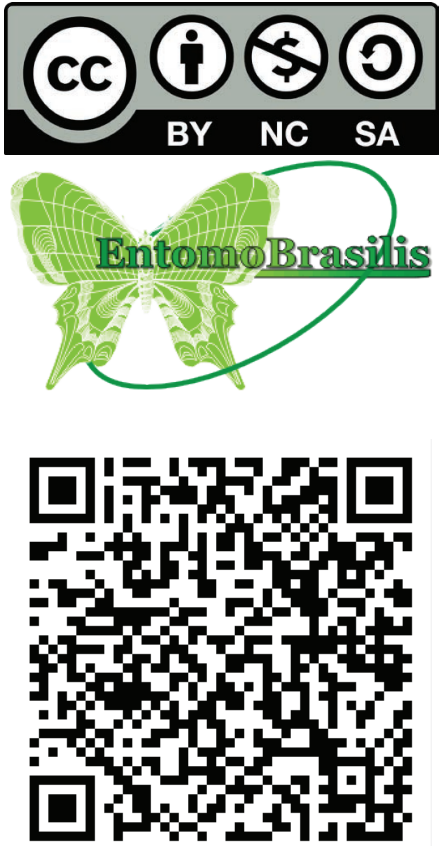